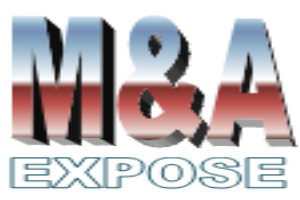

http://jurnal.usahid.ac.id/index .php/accounting
${ }^{1}$ Fakultas Ekonomi dan Bisnis

Universitas Sahid

kasman paduko@yahoo.com

\section{Analisis Keputusan Sumber Dana Pengembangan Usaha untuk Meningkatkan Nilai Perusahaan}

\section{Kasman $^{1}$}

\section{Abstrak}

Tujuan penelitian ini untuk menganalisis keputusan perusahaan dalam melakukan pengembangan usaha dengan menggunakan sumber dana Modal Sendiri untuk meningkatkan nilai perusahaan. Metode analisis yang digunakan adalah metode analisis perbandingan sumber dana Modal Sendiri atau Utang Jangka Panjang, Degree of Financial Leverage (DFL), Degree of Total Leverage (DTL), dan Degree of Operating Leverage (DOL). Hasil penelitian menunjukkan bahwa pada saat perusahaan melakukan pengembangan usaha menggunakan dana dari modal sendiri (saham) 100 persen maka EPSnya lebih rendah daripada pada saat menggunakan utang jangka panjang (obligasi) 100 persen. Hal ini menunjukkan bahwa pemilihan dana untuk pengembangan usaha perusahaan pada tahun terakhir yang menggunakan modal sendiri (saham) 100 pesen pada tidak tepat karena menghasilkan EPS rendah. Semakin tinggi EPS akan menyebabkan naiknya harga saham, hal ini akan meningkatkan nilai perusahaan. DFL dan DTL juga lebih tinggi jika menggunakan dana pengembangan usaha yang bersumber dari utang jangka panjang 100 persen, dibandingkan dengan menggunakan modal sendiri seluruhnya.

Kata kunci : pengembangan usaha; sumber dana; nilai perusahaan.

\section{Abstract}

The purpose of this study is to analyze company decisions in conducting business development by using their own capital resources to increase company value. The analytical method used is the method of comparison analysis of Shares or Long-term Debt funding sources, Degree of Financial Leverage (DFL), Degree of Total Leverage (DTL), and Degree of Operating Leverage (DOL). The results of the study show that when the company develops a business using funds from its own capital (shares) 100 percent, the $E P S$ is lower than when using long-term debt (bonds) 100 percent. This shows that the selection of funds for business development of companies in the recent year using their own capital (shares) of 100 percent is not appropriate because it produces low EPS. The higher the EPS will cause a rise in stock prices, this will increase the value of the company. DFL and DTL are also higher if they use business development funds sourced from 100 percent long-term debt, compared to using their own capital entirely.

Keywords : business development; source of funds; firm value. 


\section{PENDAHULUAN}

Pengembangan usaha merupakan suatu keniscayaan bagi perusahaan-perusahaan Indonesia yang ingin berlomba dalam persaingan regional dan persaingan global. Di samping motif ekonomi atau motif rasional, di dalam ekspansipun terdapat motif lainnya yaitu apa yang disebut motif psychologis yaitu ekspansi yang didasarkan pada personal ambition dari pemilik atau pimpinan perusahaan untuk memperoleh prestige dan penguasaan pangsa pasar yang lebih besar.

Dengan demikian maka untuk dapat melakukan bisnisnya, setiap perusahaan selalu memerlukan aktiva riil, baik yang berwujud (tangible assets) seperti mesin, pabrik, kantor, kendaraan, maupun yang tidak berwujud (intangible assets) seperti keahlian teknis (technical expertise), merek dagang (trade mark) dan paten. Untuk memperoleh aktiva riil tersebut, perusahaan harus mencari pendanaan antara lain dengan cara menjual saham, obligasi bagi perusahaan yang berbentuk perseroan terbatas ataupun sekuritas lain atau mencari kredit dari bank. Sekuritas tersebut disebut aktiva keuangan (financial assets). Sekuritas yang merupakan aktiva keuangan tersebut mempunyai nilai sehingga dapat diperjualbelikan karena dokumen tersebut mempunyai tuntutan atau hak (claims) atas aktiva riil dari perusahaan yang menerbitkan sekuritas tersebut. Oleh karena itulah salah satu leverage mengukur perubahan pendapatan atau penjualan terhadap keuntungan operasi.

Berkaitan dengan pentingnya financial leverage dan operating leverage, maka hal ini perlu diperhatikan oleh perusahaan PT Sejuta Jaring Global, sebagai salah satu perusahaan yang bergerak di bidang jasa Tehnologi Informatika. Perusahaan saat ini membutuhkan dana untuk menjalankan proyek yang menjadi peluang usaha untuk meningkatkan laba perusahaan dan melakukan pengembangan usaha di tahun 2017. Dana untuk pengembangan usaha dapat bersumber dari modal sendiri atau hutang jangka panjang. Sumber dana yang lebih baik untuk meningkatkan nilai perusahaan perlu dianalisis karena tanpa penelitian tidak dapat menentukan sumber dana yang lebih baik (tergantung kepada struktur modal perusahaan). Penelitian pada PT. Sejuta Jaring Global dibatasi hanya menyangkut sumber dana yang digunakan untuk pengembangan usaha pada Tahun 2017. Data dibatasi pada Laporan Laba Rugi Tahun 2015 dan 2016. Tujuan penelitian ini untuk menganalisis keputusan PT. Sejuta Jaring Global dalam melakukan pengembangan usaha dengan menggunakan sumber dana modal sendiri untuk meningkatkan nilai perusahaan.

Menurut Harahap (2013:132) tujuan laporan keuangan adalah untuk membantu para pemakai yang pada pokoknya memiliki wewenang, kemampuan, atau sumber yang terbatas untuk mendapatkan informasi dan yang meyakini laporan keuangan sebagai sumber utama informasi tentang kegiatan ekonomi perusahaan. Keputusan penggunaan dana (investasi) tampak dalam sisi aktiva neraca, sedangkan keputusan pendanaan sumber dana tampak pada sisi pasiva neraca. Sumber pendanaan ditinjau dari asalnya dapat dibedakan menjadi sumber intern dan sumber ekstern. Sumber internal terdiri dari laba ditahan dan akumulasi penyusutan. Sumber dana ekstern adalah sumber dana yang berasal dari luar perusahaan. Cara pembelanjaan di mana usaha pemenuhan kebutuhan dana diambilkan dari sumbersumber dana yang berasal dari luar perusahaan disebut external financing. Dana yang berasal dari luar dibedakan atas dana dari kreditur (hutang) dan dana dari pemilik (modal sendiri). Modal/dana yang berasal dari kreditur disebut hutang atau modal asing. Cara pemenuhan kebutuhan dana dengan menggunakan modal asing disebut debtfinancing. Dana yang berasal dari pemilik atau pengambil bagian dalam perusahaan adalah 
merupakan dana yang akan tetap tertahan dalam perusahaan, sehingga disebut modal sendiri. Cara pemenuhan kebutuhan dana dengan menggunakan dana yang berasal dari pemilik disebut equity financing.

Perusahaan menggunakan rasio leverage dengan tujuan agar keuntungan yang diperoleh lebih besar biaya assets dan sumber dananya, dengan demikian akan meningkatkan keuntungan pemegang saham. Syamsuddin (2012:90) mengemukakan bahwa rasio leverage merupakan kemampuan perusahaan untuk menggunakan aktiva atau dana yang mempunyai beban tetap (fixed cost assets or funds) yang digunakan untuk memperbesar tingkat penghasilan (return) bagi pemilik perusahaan. Leverage perusahaan akan mempengaruhi laba per lembar saham, tingkat risiko dan harga saham. Nilai perusahaan yang tidak mempunyai hutang untuk pertama kali akan naik pada saat kebutuhan tambahan modal dipenuhi oleh hutang. Selanjutnya nilai tersebut akan mencapai puncaknya dan akhirnya nilai itu akan menurun setelah penggunaan hutang berlebihan.

Sedangkan menurut Martono dan Harjito (2008:295), rasio leverage mengacu pada penggunaan aset dan sumber dana oleh perusahaan di mana dalam penggunaan asset atau dana tersebut perusahaan harus mengeluarkan biaya tetap atau beban tetap. Dari definisi tersebut di atas dapat disimpulkan bahwa penggunaan dana aset atau dana tersebut pada akhirnya dimaksudkan untuk meningkatkan keuntungan potensial bagi pemegang saham. Dalam perusahaan dikenal dua macam leverage, yaitu leverage operasi (operating leverage) dan leverage keuangan (financial leverage). Penggunaan kedua leverage ini bertujuan agar keuntungan yang diperoleh lebih besar daripada biaya asset dan sumber dananya.

Warsono (2008:204) mengemukakan bahwa financial leverage adalah setiap penggunaan aset atau dana yang membawa konsekuensi biaya dan beban tetap. Beban tetap yang dimaksud adalah dapat berupa bunga pinjaman, jika perusahaan menggunakan sumber pembelanjaan dari luar (modal asing), sedangkan apabila perusahaan menggunakan mesin-mesin, maka harus menanggung beban tetap yang berupa biaya penyusutan mesin-mesin (depresiasi). Kalau perusahaan menyewa suatu aktiva tetap kepada pihak lain, maka konsekuensinya harus membayar biaya tetap berupa biaya sewa.

Sutrisno (2010:230) mengemukakan pengertian financial leverage bahwa financial leverage terjadi akibat perusahaan menggunakan sumber dana dari hutang yang menyebabkan perusahaan harus menanggung beban tetap, atas penggunaan dana perusahaan tersebut setiap tahunnya maka dibebani biaya bunga. Yamit (2011:87) berpendapat bahwa financial leverage adalah pengaruh perubahan modal terhadap pendapatan bersih operasi (net operating income $=\mathrm{NOI}$ ) atau terhadap profitabilitas perusahaan. Berdasarkan uraian tersebut di atas, maka dapat ditarik kesimpulan bahwa financial leverage merupakan usaha memperbesar efek perubahan atas laba sebelum pajak dan bunga/earning before interests and taxes (EBIT) terhadap pendapatan per lembar saham/per share (EPS).

Apabila dalam operating leverage, masalah fixed costs/aset tetap yang memengaruhi laba perusahaan dalam financial leverage adalah biaya modal tetap (fixed financial cost). Biaya modal tetap merupakan suatu bunga tetap (fixed interests) yang harus dibayar perusahaan sesuai dengan perjanjian kepada pemberi pinjaman (debt holdres) atau dividen atas saham preferen (preferred stockholders) sebelum pembagian pendapatan/ dividen kepada para pemegang saham umum/saham biasa (common stockholders). Menurut 
Gitosudarmo (2011:228) berpendapat bahwa ada dua macam leverage, yaitu Operating Leverage dan Financial Leverage

Konsep operating leverage menganalisis sejauh mana sales revenue dapat menutup biaya tetap dan biaya variabel. Operating leverage adalah penggunaan sesuatu kekayaan atau aktiva tertentu yang akan mengakibatkan beban tetap bagi perusahaan seperti mesinmesin, gedung dan sebagainya. Dalam hal ini beban tetapnya akan berupa biaya depresiasi. Operating leverage merupakan tingkat kepekaan pendapatan sebelum bunga dan pajak (Earning Before Interest and Taxes) karena perubahan dari volume penjualan.

Leverage keuangan menurut Sinuraya (2008:129) adalah besarnya beban tetap keuangan (financial) yang digunakan oleh perusahaan. Beban tetap keuangan tersebut biasanya berasal dari pembayaran bunga untuk utang yang digunakan oleh perusahaan. Karena itu pembicaraan leverage keuangan berkaitan dengan struktur modal perusahaan. Perusahaan yang menggunakan beban tetap (bunga) yang tinggi berarti menggunakan utang yang tinggi. Perusahaan tersebut dikatakan mempunyai leverage keuangan yang tinggi, yang berarti degree of financial leverage (DFL) untuk perusahaan tersebut juga tinggi.

Syamsuddin (2012:90) mengemukakan bahwa rasio leverage merupakan kemampuan perusahaan untuk menggunakan aktiva atau dana yang mempunyai beban tetap (fixed cost assets or funds) yang gunanya untuk memperbesar tingkat penghasilan (return) bagi pemilik perusahaan. Dari definisi tersebut di atas dapat disimpulkan bahwa penggunaan dana asset (aktiva) atau dana tersebut pada akhirnya dimaksudkan untuk meningkatkan keuntungan potensial bagi pemegang saham. Dalam suatu perusahaan dikenal dua macam leverage, yaitu leverage operasi (operating leverage) dan leverage keuangan (financial leverage). Penggunaan kedua leverage ini dengan tujuan agar keuntungan yang diperoleh lebih besar daripada biaya asset dan sumber dananya.

Pengembangan usaha (Atmaja, 2008: 131) dalam suatu perusahaan dapat terjadi disebabkan oleh salah satu dari lima hal dibawah yaitu penggantian (replacement) untuk mempertahankan bisnis yang ada, penggantian untuk mengurangi biaya, pengembangan produkyang ada, pengembangan produk baru, dan peralatan keamanan dan lingkungan. Memaksimumkan nilai perusahaan (Margaretha, 2005:1) artinya lebih luas dari memaksimumkan laba perusahaan, karena tiga alasan pokok yaitu waktu, arus kas masuk yang akan diperoleh pemegang saham, dan risiko.

\section{METODE PENELITIAN}

Terdapat dua hal utama yang mempengaruhi kualitas data hasil penelitian, yaitu kualitas instrumen penelitian dan kualitas pengumpulan data. Kualitas instrumen penelitian berkenaan dengan validitas dan reliabilitas instrumen dan kualitas pengumpulan data berkenaan dengan ketepatan cara-cara yang digunakan untuk mengumpulkan data. Oleh karena itu instrumen yang telah teruji validitas dan reliabilitasnya, belum tentu dapat menghasilkan data yang valid dan reliable, apabila instrument tersebut tidak digunakan secara tepat dalam pengumpulan datanya

Adapun jenis data yang digunakan dalam penulisan ini adalah data sekunder kuantitatif, yaitu data yang diperoleh dari perusahaan berupa angka-angka yang dapat dihitung seperti nilai pendapatan dan data lainnya yang dapat mendukung pembahasan. Sedangkan sumber data yang akan dianalisis adalah data sekunder yaitu data yang 
diperoleh dengan mengumpulkan dokumen-dokumen serta sumber-sumber lainnya yang berupa informasi laporan keuangan pada PT Sejuta Jaring Global di Jakarta. Data sekunder merupakan sumber data penelitian yang diperoleh peneliti secara tidak langsung melalui media perantara (diperoleh atau dicatat oleh pihak lain). Data sekunder umumnya berupa bukti, catatan atau laporan historis yang telah tersus

Pengumpulan data dapat dilakukan dalam berbagai setting, berbagai sumber, dan berbagai cara. Bila dilihat dari setting-nya, data dapat dikumpulkan pada settingan alamiah (natural setting). Pada laboratorium dengan metode eksperimen, dirumah dengan berbagai macam responden, pada suatu seminar, diskusi dan lain sebagainya. Dan dilihat dari sumber datanya, maka pengumpulan data menggunakan sumber sekunder., dan sumber sekunder merupakan sumber yang tidak langsung memberikan data kepada peneliti, misalnya melalui orang lain atau lewat dokumen. Selanjutnya bila dilihat dari segi cara atau tehnik pengumpulan data, maka pengumpulan data dapat dilakukan dengan metode Dokumentasi, yaitu mengumpulkan data yang dapat dijadikan sebagai bahan penelitian yang berasal dari arsip-arsip yang dimiliki oleh perusahaan yang dianggap mampu memberikan data yang signifikasi dengan masalah yang akan diteliti

Adapun analisis yang digunakan dalam penulisan ini adalah :

1. Analisis Komparatif antara penggunaan sumber dana Modal Sendiri dengan hutang jangka panjang. Analisis ini menentukan Earning Per Share (EPS) pada realisasi Laba/Rugi yang telah diperoleh Perusahaan setelah menggunanakan sumber dana sendiri. Kemudian dibandingkan dengan EPS yang dihitung dengan menggunakan Laba/Rugi jika perusahaan menggunakan utang jangka panjang.

$\mathrm{EPS}=\frac{\text { Laba Bersih Setelah Pajak }}{\text { Jumlah Lembar Saham Beredar }}$

2. Analisis financial leverage. Analisis financial leverage yaitu suatu analisis untuk melakukan perbandingan EBIT dengan Earning Per Share, dengan rumus :

a. Degree of Financial Leverage (DFL)

Untuk mengukur seberapa besar pengaruh perubahan EBIT terhadap perubahan laba perusahaan digunakan tingkat leverage keuangan. Menurut Warsono (2003:218) DFL dapat diformulasikan sebagai berikut :

$\mathrm{DFL}=\frac{\text { Persentase Perubahan } E P S}{\text { Persentase Perubahan } E B I T}$

b. Degree of Total Leverage (DTL)

Untuk mengukur seberapa besar pengaruh perubahan volume penjualan terhadap perubahan laba perusahaan digunakan tingkat leverage total (degree of total leverage). Secara matematis, Warsono (2003 : 223) DTL diformulasikan sebagai berikut :

$\mathrm{DTL}=\frac{\text { Persentase Perubahan EPS }}{\text { Persentase Perubahan Penjualan }}$ 
c. Degree of Operating Leverage (DOL)

Untuk mengukur seberapa besar pengaruh perubahan volume penjualan terhadap perubahan EBIT dapat digunakan tingkat leverage operasi (degree of operating leverage (DOL). Secara matematis, Warsono (2003:215) DOL dapat diformulasikan sebagai berikut :

$$
D O L=\frac{\text { Persentase Perubahan } E B I T}{\text { Persentase Perubahan Penjualan }}
$$

\section{HASIL DAN PEMBAHASAN}

Kebutuhan dana untuk perluasan usaha sebesar Rp 500.000.000, pada awal tahun 2016 dipenuhi dengan menerbitkan saham biasa baru 100 persen. Berikut ini disajikan data pertumbuhan EBIT, EAT dan nilai nominal Saham Baru sama dengan nilai nominal saham lama. Nilai Nominal Saham Rp. 10.000 per lembar saham, bunga obligasi baru sebesar 7 persen. Struktur Modal PT Jaring Global sebelum perluasan Usaha pada Tahun 2016 terdiri dari Saham Biasa 100 persen yaitu sebesar Rp 500.000.000 dan tidak punya hutang jangka panjang, dengan nilai nominal $\mathrm{Rp} 10.000$ per lembar $=50.000$ lembar saham .

Tabel 1. Laba Per Lembar Saham (EPS)

PT. Sejuta Jaring Global sebelum perluasan Usaha Tahun 2016

\begin{tabular}{ll}
\hline EBIT & -33.348 .579 \\
EBIT & $(35,268.579)$ \\
Bunga Obligasi (6\%) & $(-)$ \\
Keuntungan (Kerugian)Sebelum Pajak (EBT) & $(35,268.579)$ \\
Pajak Penghasilan (25\%) & 0 \\
Keuntungan (Kerugian) Netto Setelah Pajak (EAT) & $(35,268.579)$ \\
Pendapatan Per Lembar Saham (EPS) & $-(667)-$ \\
EAT/ Jumlah Lembar Saham &
\end{tabular}

Sumber : Diolah dari Laporan L/R PT. Sejuta Jaring Global Tahun 2016

Sebelum perluasan pada usaha pada Tahun 2016 PT. Sejuta Jaring Global mengalami kerugian sebesar Rp 35.268.579 dan Laba Per Lembar Saham (EPS) Rp. (667). Setelah perluasan usaha pada akhir tahun 2017 PT. Sejuta Jaring Global dapat menghasilkan Laba Bersih setelah pajak Rp 6.966.565 dan menghasilkan EPS Rp 69 dengan sumber untuk perluasan usaha seluruh sumber dana diperoleh dari emisi saham baru 100 persen. Kemudian pada kolom 2 tabel berikut diperlihatkan EPS yang diperoleh jika sumber dana untuk perluasan diperoleh dari emisi obligasi 100 persen. 
Tabel 2. Laba Per Lembar Saham (EPS)

PT. Sejuta Jaring Global setelah mengadakan perluasan usaha perluasan usaha Tahun 2016

\begin{tabular}{lll}
\hline & $\begin{array}{l}\text { Yang telah dilakukan PT. } \\
\text { Jaring Global Emisi Saham } \\
100 \%\end{array}$ & $\begin{array}{l}\text { Asumsi lain jika melakukan } \\
\text { emisi saham 0 \% dan } \\
\text { Obligasi 100\% }\end{array}$ \\
\hline EBIT & 9.231 .421 & 9.231 .421 \\
\hline Bunga Obligasi (7\%) & $(-)$ & 815.599 \\
\hline $\begin{array}{l}\text { Keuntungan Sebelum Pajak } \\
\text { (EBT) }\end{array}$ & 9.231 .421 & 8.379 .822 \\
\hline Pajak Penghasilan (25\%) & 2.307 .856 & 2.094 .955 \\
\hline $\begin{array}{l}\text { Keuntungan Netto Setelah } \\
\text { Pajak (EAT) }\end{array}$ & 6.926 .565 & 6.284 .867 \\
\hline $\begin{array}{l}\text { Pendapatan Per Lembar } \\
\begin{array}{l}\text { Saham (EPS) } \\
\text { EAT/ Jumlah Lembar Saham }\end{array}\end{array}$ & 69 & $\mathbf{1 2 6}$ \\
\hline $\begin{array}{l}\text { Sumber: Dion dari Laporan } \\
\text { Sa PT. Sejuta Jaring Global Tahun } 2017\end{array}$ & \\
\hline
\end{tabular}

Sumber : Diolah dari Laporan L/R PT. Sejuta Jaring Global Tahun 2017

Kebijakan PT. Sejuta Jaring Global memenuhi kebutuhan dana pada tahun 2016 dengan mengadakan emisi saham 100 persen hanya memberikan EPS Rp 69, sedangkan jika mengadakan emisi saham 0 persen dan emisi obligasi 100 persen menghasilkan EPS Rp 126. Dalam mempertimbangkan sumber dana mana yang akan digunakan, sangat penting memperhatikan berapa besar EPS yang akan diperoleh, semakin besar EPS yang diperoleh semakin baik, karena semakin besar EPS maka semakin besar kemampuan perusahaan membagikan dividen kepada para pemegang saham. Semakin besar Dividen yang dibagikan kepada para pemegang saham akan mengakibatkan pengaruh positif kepada kenaikan harga saham. Dari data diatas maka dapat di hitung tingkat Degree of Financial Leverage dari berbagai macam tingkat alternatif pendanaan dalam perusahaan dengan menggunakan rumusan sebagai berikut:

DFL $1=\frac{\frac{69-(-705)}{(-705)}}{\frac{(9.231 .421)-(-35.268 .579)}{(-35.268 .579)}}$

DFL $1=0,87$

Artinya dari hasil perhitungan DFL alternatif 1 yang menunjukkan bahwa setiap peningkatan EBIT sebesar 100 persen akan meningkatkan laba bersih per lembar saham (EPS) sebesar 95 persen. Dan tingkat Degree of Financial Leverage untuk alternatif 2 dengan pendanaan melalui hutang sebesar 100 persen melalui Obligasi, maka akan menghasilkan:

DFL $2=\frac{\frac{(126)-(-705)}{(-705)}}{\frac{(9.231 .421)-(-35.268 .579)}{(-35.268 .579)}}$

DFL $2=0,95$ 
Artinya dari hasil perhitungan DFL alternatif 2 yang menunjukkan bahwa setiap peningkatan EBIT sebesar 100 persen akan meningkatkan laba bersih perlembar saham (EPS) sebesar 95 persen. DFL 2 Lebih tinggi daripada DFL 1 maka PT. Sejuta Jaring Global pada Tahun 2017 pada kondisi struktur modal tersebut lebih baik memilih Alternatif 2 yaitu mengadakan emisi Obligasi 100 persen karena DFLnya lebih tinggi. DTL menunjukkan perubahan EPS akibat perubahan penjualan. Selanjutnya akan disajikan pertumbuhan Leverage Total yang dapat dihitung dengan rumus sebagai berikut :

DTL $1=\frac{\frac{69-(-705)}{(-705)}}{\frac{(537.239 .225)-322.239 .225}{322.239 .225}}$

DTL $1=1,67$

Artinya dari hasil perhitungan DTL alternatif 1 yang menunjukkan bahwa setiap peningkatan EBIT sebesar 100 persen akan meningkatkan laba bersih per lembar saham (EPS) sebesarr 167 persen. Dan tingkat Degree of Total Leverage untuk alternatif 2 dengan pendanaan melalui hutang sebesar 100 persen melalui obligasi, maka akan menghasilkan:

DTL $2=\frac{\frac{(126)-(-705)}{(-705)}}{\frac{537.239 .225-322.239 .225}{322.239 .225}}$

DTL $2=1,82$

Artinya dari hasil perhitungan DTL alternatif 2 yang menunjukkan bahwa setiap peningkatan EBIT sebesar 100 persen akan meningkatkan laba bersih per lembar saham (EPS) sebesar 182 persen. Salah satu upaya yang dilakukan oleh setiap perusahaan dalam pengelolaan aktivitas usahanya adalah dengan mengelola aktivitasnya secara efisien dan efektif, sehingga dengan mengelola aktivitasnya secara efisien dan efektif maka salah satu faktor yang perlu diperhatikan oleh perusahaan adalah aspek permodalan. Aspek permodalan dalam perusahaan sangat berpengaruh dalam membelanjai setiap aktivitas operasional perusahaan, di mana tanpa aspek permodalan maka perusahaan tidak akan dapat melakukan aktivitasnya sesuai dengan yang direncanakan. Agar aspek permodalan dapat digunakan sesuai dengan yang diharapkan maka perusahaan perlu menetapkan struktur modal. Struktur modal adalah perimbangan antara modal sendiri dengan modal pinjaman yang digunakan dalam membelanjai setiap aktivitas operasional perusahaan.

Aspek permodalan yang menjadi titik pokok dalam penelitian ini adalah Degree Operating Leverage (DOL) yaitu perbandingan perubahan EBIT dengan penjualan. Analisis DOL adalah suatu analisis untuk melakukan perbandingan antara perubahan EBIT dengan pendapatan termin proyek. Maka tingkat Degree of Operating Leverage untuk alternatif 1 dengan pendanaan melalui modal sendiri sebesar 100\%, maka akan menghasilkan: 
DOL $1=\frac{\frac{(9.231 .421)-(-35.268 .579)}{(-35.268 .579)}}{\frac{537.239 .225-322.239 .225}{322.239 .225}}$

DOL $1=1,91$

Artinya dari hasil perhitungan DOL alternatif 1 yang menunjukkan bahwa setiap kenaikan dalam pendapatan meningkatkan EBIT sebesar 191 persen. Dan tingkat Degree of Operating Leverage untuk alternatif 2 dengan pendanaan melalui hutang sebesar 100 persen melalui obligasi, maka akan menghasilkan :

DOL $2=\frac{\frac{(9.231 .421)-(-35.268 .579)}{(-35.268 .579)}}{\frac{537.239 .225-322.239 .225}{322.239 .225}}$

DOL $2=1,91$

Artinya dari hasil perhitungan DOL alternatif 2 yang menunjukkan bahwa setiap kenaikan pendapatan 100 persen akan meningkatkan EBIT sebesar 191 persen. Pendanaan tidak terlepas dari struktur keuangan yang ada, yang akan berdampak pada struktur modal perusahaan. Struktur modal sendiri adalah cara bagaimana perusahaan membiayai aktivanya, dan struktur keuangan nampak pada neraca pada sisi pasivanya. Dengan demikian struktur keuangan perusahaan terdiri dari hutang jangka pendek, hutang jangka panjang, dan modal saham. Struktur keuangan mengatur jenis sumber dana yang ditinjau dari jangka waktunya, apakah dibiayai dengan dana jangka pendek atau dana jangka panjang.

Struktur modal adalah merupakan bagian dari struktur keuangan, sebab struktur modal atau kapitalisasi hanya menyangkut sumber pendanaan jangka panjang atau sumber dana yang sifatnya relatif permanen. Oleh karenanya struktur modal terdiri dari hutang jangka panjang, saham preferen dan saham biasa. Saham preferen sebenarnya merupakan kombinasi antara bentuk hutang dan modal sendiri. Pemegang saham preferen berhak atas deviden yang tetap besarnya, berapapun keuntungan yang diperoleh perusahaan. Sesuai dengan UU no. 1 tahun 1995 tentang Perseroan Terbatas, menyebutkan bahwa perusahaan dapat menerbitkan saham yang mempunyai karakteristik khusus yang harus diperjelas dalam Anggaran Dasarnya. Karakteristik tersebut misalnya: hak suara khusus, bersyarat, terbatas atau tanpa hak suara. Sebenarnya yang dimaksud adalah saham preferen.

Dengan kata lain dapat pula dikatakan bahwa kapitalisasi itu merupakan jumlah modal yang terikat dalam perusahaan yang meliputu hutang jangka panjang dan modal sendiri. Sedangkan struktur modal adalah perimbangan atau perbandingan antara hutang jangka panjang denga modal sendiri.

Kebijakan PT. Seribu Jaring Global memperoleh dana berupa Saham / Modal sendiri 100 persen belum dapat mingkatkan nilai perusahaan. Nilai perusahaan dapat dilihat dari harga saham. Perusahaan yang dapat memperoleh EPS yang meningkat cenderung meningkatkan harga sahamnya di Bursa Efek. Direktur Keuangan PT. Sejuta Jaring Global memilih sumber dana berupa saham baru 100 persen hanya menghasilkan EPS Rp 69, 
sedangkan apabila sumber dana diperoleh dari Obligasi / hutang jangka panjang $100 \%$ maka EPS yang diperoleh adalah Rp 126.

\section{KESIMPULAN}

Berdasarkan analisis dan pembahasan yang telah diuraikan sebelumnya, maka dapat disimpulkan bahwa PT. Sejuta Jaring Global saat membutuhkan sumber dana untuk ekspansi sebesar Rp 500.000.000 menggunakan sumber dana dari emisi saham biasa 100 persen, dan menghasilkan EPS Rp 69. Kebijakan ini tidak dapat meningkatkan nilai perusahaan. Sebaliknya jika menggunakan Obligasi 100 persen maka menghasilkan EPS 126. Dari hasil DFL, DOL dan DTL terlihat bahwa sumber dana dari Obligasi/Hutang jangka panjang 100 persen menghasilkan DFL dan DTL yang lebih tinggi, sedangkan DOL tidak mengalami perubahan. Hasil penelitian ini tidak bisa berlaku secara umum untuk seluruh perusahaan karena struktur modal perusahaan yang berbeda akan berbeda pula. Jadi untuk mengetahui sumber dana mana yang lebih baik dipilih oleh perusahan lain sebaiknya melakukan penelitian per kasus. Penelitian ini hanya membatasi pada financial leverage dan tidak meneliti kemampuan perusahaan membayar bunga setiap periode dan melunasi hutang jangka panjang saat jatuh tempo. Untuk mengetahui kemampuan perusahaan dalam hal pembayaran bunga hutang dan kemampuan melunasi hutang jangka panjang saat jatuh tempo diperlukan penelitian lebih lanjut.

\section{DAFTAR PUSTAKA}

Ajmaja, Lukas Setia. 2008. Teori dan Praktek Manajemen Keuangan. Penerbit Andi. Yogyakarta.

Ekayanti, I Ketut. Ni Putu Nova. dan Suryanawa. 2013. Pengaruh EPS Terhadap Harga Saham dengan Dividend Per Share Sebagai Variabel Moderasi. E-Jurnal Akuntansi. Universitas Udayana. Vol 3. No.2.

Hanafi, Mamduh. 2012. Manajemen Risiko. Edisi 2. UPP STIM YKPN. Yogyakarta.

Harahap, Sofyan. dan Syafri. 2013. Analisis Kritis Atas Laporan Keuangan. Cetakan ke-11. Raja Grafindo Persada. Jakarta.

Lutvi Savitri, Abied. 2013 .Pengaruh EPS, PER, ROA, Debt to Equity Ratio dan Market Value Added Terhadap Harga Salam Dalam Kelompok Jakarta Islamic Index. Manajemen Analisis Jurnal. Unnes. Vol.2 No.2.

Margaretha, Farah. 2005. Teori Dan Aplikasi Manajemen Keuangan. Investasi dan Sumber Dana Jangka Pendek. Gramedia Widiasarana Indonesia. Jakarta.

Sinuraya, Murthada. 2008. Teori Manajemen Keuangan. Edisi Kedua. Penerbit : Fakultas Ekonomi. Universitas Indonesia. Jakarta.

Syamsuddin, Lukman. 2012. Manajemen Keuangan Perusahaan. Edisi Baru. Rajawali Pers. Jakarta.

Sugiyono. 2011. Metode Penelitian Kuantitatif, Kualitatif, Dan R\&D. Alfabeta. Bandung.

Sutrisno. 2010. Manajemen Keuangan: Teori, Konsep dan Aplikasi. Edisi Pertama. Cetakan ketiga. Penerbit : Ekonisia. Yogyakarta.

2013. Metode Penelitian Manajemen. Pendekatan: Kuantitatif, Kombinasi (Mixed Methods), Penelitian Tindakan (Action Research). Penelitian Evaluasi. Alfabeta. Bandung. 
Warsono. 2008. Manajemen Keuangan Perusahaan. Edisi ketiga. Cetakan Pertama. Jilid satu. Bayu Media: Malang.

Yamit, Zulian. 2011. Manajemen Keuangan. Edisi Pertama. Cetakan ketiga. Ekonisia: Yogyakarta. 